\title{
CORRELATION BETWEEN LDL, HDL, AND TRIGLYCERIDE CONDITIONS WITH BODY FAT PERCENTAGE OF UNIVERSITAS PADJADJARAN PROFESSORS
}

\author{
Yosi Wailan Saputra ${ }^{1}$, Miftahurachman ${ }^{2}$, Leonardo Lubis ${ }^{3}$ \\ ${ }^{1}$ Medical Doctor Program, ${ }^{2}$ Department of Internal Medicine, ${ }^{3}$ Department of Anatomy, Physiology and Biology, \\ Faculty of Medicine, Universitas Padjadjaran/Hasan Sadikin Hospital, Bandung, Indonesia
}

\begin{abstract}
ABSTRAK
Usia lanjut, seperti pada mayoritas Guru Besar Universitas Padjadjaran (Unpad), merupakan masalah yang dapat mengganggu keseimbangan berbagai molekul di dalam tubuh, terutama molekul lemak yang berdampak pada munculnya berbagai penyakit sehingga pemeriksaan kadar lemak darah dan adiposa perlu dilakukan secara rutin dan berkala sebagai upaya deteksi dini. Penelitian ini bertujuan untuk mengetahui bagaimana hubungan antara kadar Low Density Lipoprotein (LDL), High Density Lipoprotein (HDL), dan trigliserida dengan persentase lemak tubuh pada guru besar Unpad. Studi ini adalah studi analitik regresi linear yang dilakukan terhadap 52 orang Guru Besar Unpad (o 75\%, ㅇ 25\%) berdasarkan data kadar LDL, HDL, dan trigliserida yang diperoleh melalui pemeriksaan laboratorium, serta data persentase lemak tubuh dengan menggunakan metode Bio Impedance Analysis (BIA). Hubungan antara kadar Low Density Lipoprotein (LDL), High Density Lipoprotein (HDL), dan trigliserida dengan persentase lemak tubuh pada kelompok guru besar laki-laki adalah $R^{2}=0.072 ; P>0.05$ dan perempuan adalah $\left(R^{2}=0.028 ; P>0.05\right)$. Sebagai simpulan, tidak ada hubungan antara kadar Low Density Lipoprotein (LDL), High Density Lipoprotein (HDL), dan trigliserida dengan persentase lemak tubuh pada guru besar Unpad. (FMI 2017;53:173-176)
\end{abstract}

Kata kunci: Guru Besar; HDL; LDL; persentase lemak tubuh; trigliserida

\begin{abstract}
Elderly is a problem that may disrupt the balance of various molecules in the body, especially fat molecules, which may result in the emergence of various diseases so that blood fat and adipose level examinations need to be done regularly and periodically as an effort of early detection. This study aimed to find correlation between Low Density Lipoprotein (LDL), High Density Lipoprotein $(H D L)$, and triglyceride with body fat percentage among professors in Universitas Padjadjaran (Unpad) who were mostly in elderly age. This study was a linear regression analytical study conducted on 52 Unpad professors (O 75\%, + 25\%) based on data of LDL, $H D L$, and triglyceride levels obtained through laboratory examination, as well as body fat percentage data by using Bio Impedance Analysis (BIA). The correlation between low density lipoprotein (LDL), High Density Lipoprotein (HDL), and triglyceride with body fat percentage in male professors group was $R^{2}=0.072 ; P>0.05$ and in female was $R^{2}=0.028 ; P>0.05$. As a conclusion, there was no correlation between Low Density Lipoprotein (LDL), High Density Lipoprotein (HDL), and triglyceride with body fat percentage in Unpad professors. (FMI 2017;53:173-176)
\end{abstract}

Keywords: Professors; HDL; LDL; body fat percentage; triglyceride

Correspondence: Yosi Wailan Saputra, Faculty of Medicine, Universitas Padjadjaran, Bandung, Indonesia.

Email: yosiwsaputra@gmail.com

\section{INTRODUCTION}

As we get older, the body's ability to maintain the balance of every system begins to decline. When there is a problem with the body system which cannot be compensated, it may have impacts that may manifest as the emergence of diseases. The decline in the body system is characterized by a decrease in productivity at age of 40s and will continue beyond the age of 65 that belongs to the category of elderly (Stroebe 2010). The professors in Universitas Padjadjaran (Unpad) are included in that age range. If there is a decline in the quality of health in those professors, there may be an impact on the quality of academic community in Universitas Padjadjaran.
Considering body composition, fat is the molecule that most commonly increases in elderly. Furthermore, it is necessary to check the fat in body to evaluate the possibility of system disorder, thus it may be handled immediately (Kamso 2007). Fat examination methods can be classified into two ways, by determining fat levels in blood and in adipose tissue (Darmastomo 2009).

In blood, fats undergo modification into several types of macromolecule complex to be able to dissolve, such as Low Density Lipoprotein (LDL), High Density Lipoprotein (HDL), and triglyceride. These three complex macromolecules are often referred to blood lipid 
profiles (Murray 2012). The examination method of LDL, HDL, and triglyceride levels so far is still a constraint because its process is quite complicated, and its cost is fairly expensive. Because of this problem, more practical and inexpensive alternative methods are needed with good accuracy, such as body fat examination using Bio Impedance Analysis (BIA) method. BIA is a simple, non-invasive, and fast body-checking method with less than $1 \%$ error when it is re-measured (Dehghan \& Merchant 2008). To find the correlation between LDL, HDL, and triglyceride levels with body fat percentage, a study on the correlation between LDL, HDL, and triglyceride levels with body fat percentage in Unpad professors was carried out.

\section{MATERIALS AND METHODS}

This linear regression analysis study was conducted in February-November 2016 at Universitas Padjadjaran. Data collection was conducted in September-November 2016. The study has met the ethical requirements of the Medical Ethics Committee of Universitas Padjadjaran.

In this study, subjects were selected from primary research data about Universitas Padjadjaran professors. Subjects were 52 professors of Universitas Padjadjaran who have fulfilled the inclusion and exclusion criteria to meet the minimum sample required. The inclusion criteria were Universitas Padjadjaran professors whose data has been collected as primary research data at Health Technical Implementation Unit of Universitas Padjadjaran from January 1 to October 29, 2015. The professors who were less than 20 years old, more than 79 years old, or who did not have necessary data were excluded from this study.

The instrument used in this study was primary data of research on Unpad professors at Health Technical Implementation Unit of Universitas Padjadjaran from January 1 to October 29, 2015. The independent variables in this study were LDL, HDL, and triglyceride levels, while the dependent variable was the percentage of body fat. Levels of LDL, HDL, and triglyceride were obtained through laboratory examination of blood lipids. Percentage of body fat obtained using Bio Impedance Analysis (BIA) method. This method has the ability to calculate the total amount of fat in adipose tissue by estimating total body fluids through a computerized system.

The data in this study were LDL, HDL, triglyceride levels in $\mathrm{mg} / \mathrm{dl}$ and body fat percentages analyzed using computer software based on statistical analysis. Before analyzing the relationship between LDL, HDL, and triglyceride levels against body fat percentage, the normality of data distribution was tested. Furthermore, the data were processed at the linear regression level to determine the existence of the correlation between one independent variable and the others. The correlation was significant if the $\mathrm{p}$ value was less than or equal to 0.05 .

\section{RESULTS}

The frequency and distribution of the subjects were classified by sex and age group according to the groupings on body fat percentage calculations. Based on the data collected, there were 52 male subjects. Four persons were in 41-60 years old and 35 persons in 61-79 years old. Female subjects were 13 who were all in 6179 years old age group.

Table 1 Characteristics of data

\begin{tabular}{|c|c|c|}
\hline \multirow[b]{2}{*}{ Characteristics } & \multicolumn{2}{|c|}{ Mean \pm Standard Deviation (SD) } \\
\hline & $\begin{array}{c}\text { Male } \\
(\underline{x} \pm \mathrm{SD})\end{array}$ & $\begin{array}{l}\text { Female } \\
\underline{x} \pm \text { SD }\end{array}$ \\
\hline Age (years old) & \multicolumn{2}{|c|}{$70.9 \pm 7.4$} \\
\hline $41-60$ & $51.5 \pm 7.2$ & 0 \\
\hline $61-79$ & $73.5 \pm 4.0$ & $70.1 \pm 5.6$ \\
\hline LDL & \multicolumn{2}{|c|}{$113.8 \pm 28.2$} \\
\hline $41-60$ & $130.8 \pm 44.1$ & 0 \\
\hline $61-79$ & $109.9 \pm 26.5$ & $\begin{array}{c}119.15 \\
27.2\end{array}$ \\
\hline HDL & \multicolumn{2}{|c|}{$46.0 \pm 8.0$} \\
\hline $41-60$ & $40.8 \pm 6.5$ & 0 \\
\hline $61-79$ & $45.6 \pm 7.9$ & $48.5 \pm 8.5$ \\
\hline Triglyceride & \multicolumn{2}{|c|}{$109.5 \pm 44.6$} \\
\hline $41-60$ & $175.5 \pm 44.1$ & 0 \\
\hline $61-79$ & $99.9 \pm 38.9$ & $\begin{array}{c}115.2 \pm \\
37.5\end{array}$ \\
\hline $\begin{array}{l}\text { Body fat } \\
\text { percentage }\end{array}$ & \multicolumn{2}{|c|}{$27.10 \pm 5.2$} \\
\hline $41-60$ & $26.7 \pm 2.8$ & 0 \\
\hline $61-79$ & $27.3 \pm 5.4$ & $26.0 \pm 5.2$ \\
\hline
\end{tabular}

The data normality test in this study was done. either in whole or in each data group with $\mathrm{p}$ value of $>0.05$. This value proved that all data groups used in this study had normal distribution. The correlation between LDL, HDL, and triglyceride levels with body fat percentage may be observed by looking at the number of correlation coefficient, coefficient of determination, and $\neg \mathrm{P}$ value shown in Table 2.

Based on statistical analysis using linear regression test, the relationship between LDL, HDL, and triglyceride levels with body fat percentage, both in total group and groups based on age group and gender, had correlation coefficient $(R)$ higher than 0.05 . It means that inde- 
pendent variables did not meet linearity criteria towards dependent variable in this study. Thus, any independent variable was not considered to have contribution to the dependent variable. It was also supported by an insignificant $\mathrm{p}$ value $(\mathrm{P}>0.05)$.

Table 2. The correlation between LDL, HDL, and triglyceride levels with body fat percentage

\begin{tabular}{lccc}
\hline \multicolumn{1}{c}{ Characteristics } & $\mathrm{R}$ & $\mathrm{R}^{2}$ & $\mathrm{P}$ value \\
\hline Male & & & \\
$\quad$ LDL, HDL, Triglyceride & 0,286 & 0.072 & 0.449 \\
$\quad \begin{array}{l}\text { LDL, Triglyceride } \\
\text { Triglyceride }\end{array}$ & 0.246 & 0.061 & 0.324 \\
61-79 & 0.183 & 0.033 & 0.266 \\
$\quad$ LDL, HDL, Triglyceride & 0.304 & 0.092 & 0.385 \\
$\quad$ LDL, Triglyceride & 0.289 & 0.083 & 0.248 \\
$\quad$ Triglyceride & 0.206 & 0.043 & 0.234 \\
Female & & & \\
$\quad$ LDL, HDL, Triglyceride & 0.303 & 0.036 & 0.233 \\
$\quad$ LDL, Triglyceride & 0.301 & 0.036 & 0.106 \\
$\quad$ Triglyceride & 0.248 & 0.030 & 0.052 \\
Total & & & \\
$\quad$ LDL, HDL, Triglyceride & 0.308 & 0.095 & 0.183 \\
$\quad$ LDL, Triglyceride & 0.308 & 0.095 & 0.087 \\
$\quad$ Triglyceride & 0.205 & 0.026 & 0.074 \\
\hline
\end{tabular}

$\mathrm{R}=$ correlation coefficient

$\mathrm{R}^{2}=$ determination coefficient

\section{DISCUSSION}

Subjects in this study were classified into elderly groups who generally had decreased ability of body functions in maintaining every function, including in controlling fat content (Stroebe 2010). The most notable increase is the one in LDL levels, both in male and female groups. However, this type of blood lipid was considered the most risky, causing the emergence of various diseases (Erwinanto et al 2013).

Based on the coefficient value of determination of each data group, each independent variable had positive contribution to dependent variable, and the independent variable which constantly had the strongest influence was triglyceride. According to biochemical point of view, fat structure, which is measured as the percentage of body fat, is the adipose tissue as the deposit of triglyceride (Murray 2012).

LDL, HDL, and triglyceride levels have very weak contribution and insignificant correlation towards the percentage of body fat due to several factors, such as the presence of some uncontrolled conditions and some variables not observed in this study that may be more influential on the results of the study. In terms of medical biochemistry, LDL, HDL, and especially triglyceride levels have important and significant role in the formation of body fat deposits in adipose tissue (Murray 2012). However, physiologically, the time span required for the metabolic process between blood fat and body fat has much differentiation. Blood fat concentration may change more rapidly than body fat whose deposit process requires a longer span of time to reach remarkable increase of its percentage (Guyton \& Hall 2007). Because of the long span of time, the various factors, such as lifestyle, greatly affect the percentage of body fat, including in the subjects of this study. Respondents who have had the habit of eating high-fat foods in years, had lacked of exercise, and later in last few weeks had controlled diet and physical activity, would get the value of blood fat levels which tended to be normal, while the percentage of body fat remained high (Sukma 2016).

This study has several limitations, such as the lack of control in patients with statin drug use. Statin drug may lower LDL levels which may make the calculations to be inaccurate (Emberson et al 2012). The next limitation of this study was that nutrition and physical activity patterns were not controlled because the required data were not sufficient to support the requirement in this study.

\section{CONCLUSION}

LDL, HDL, and triglyceride levels do not contribute significantly to the percentage of body fat although it seems to have a very small positive contribution. More powerful and significant contributions are likely to be influenced by other factors or variables.

\section{REFERENCES}

Darmastomo P (2009). Hubungan antara persentase lemak tubuh, lingkar pinggang, kolesterol total darah, dan trigliserida darah dengan tekanan darah (studi pada pegawai negeri sipil SMA 8 Semarang). Thesis, Universitas Diponegoro

Dehghan M, Merchant AT (2008). Is bioelectrical impedance accurate for use in large epidemiological studies? Nutr J. BioMed Central 7, 1.

Emberson JR, Kearney PM, Blackwell L, et al (2012). Lack of effect of lowering LDL cholesterol on cancer: Meta-analysis of individual data from 175,000 people in 27 randomised trials of statin therapy. PLoS One 7, 1-10.

Erwinanto, Santoso A, Putranto JNE, et al (2013). Pedoman tatalaksana dislipidemia. J Kardiol Indones. 34, 245-70.

Guyton AC, Hall JE. Metabolisme lipid. Buku ajar fisiol kedokteran. $11^{\text {th }}$ ed. Jakarta: EGC, p 882-94 
Kamso S. Dislipidemia dan obesitas sentral pada lanjut usia di Kota Padang. Kesmas J Kesehat Masy Nas. 2

Murray RK (2012). Harper's illustrated biochemistry. New York: McGraw-Hill Medical

Sukma AT (2016). Efek zumba terhadap penurunan tebal lemak bawah kulit dan berat badan member df fitness dan aerobic. Student Journal, Universitas Negeri Yogyakarta

Stroebe W (2005). The graying of academia: Will it reduce scientific productivity? American Psychologist. Stroebe, Wolfgang: Department of Social and Organizational Psychology, Utrecht University 